\title{
A snapshot of the limnological features in tropical floodplain lakes: the relative influence of climate and land use
}

Um "retrato" das características limnológicas das lagoas de uma planície de inundação tropical: influência relativa do clima e do uso da terra

Maria Tereza Ribeiro Alves ${ }^{1}$ (D), Karine Borges Machado ${ }^{2}$ (D), Manuel Eduardo Ferreira ${ }^{3}$ (D), Ludgero Cardoso Galli Vieira ${ }^{4}$ (D) and João Carlos Nabout ${ }^{5 *}$ (1)

${ }^{1}$ Campus de Ciências Exatas e Tecnológicas Henrique Santillo - CCET, Universidade Estadual de Goiás - UEG, BR-153, 3105, CEP 75132-903, Anápolis, GO, Brasil

${ }^{2}$ Programa de Pós-graduação em Ecologia e Evolução, Instituto de Ciências Biológicas, Universidade Federal de Goiás - UFG, Campus II, CEP 74690-900, Goiânia, GO, Brasil

${ }^{3}$ Laboratório de Processamento de Imagens e Geoprocessamento, Instituto de Estudos SócioAmbientais, Universidade Federal de Goiás - UFG, Campus II, CEP 74001-970, Goiânia, GO, Brasil

${ }^{4}$ Universidade de Brasília - UnB, Área Universitária 1, Vila Nossa Senhora de Fátima, CEP 73345-010, Planaltina, DF, Brasil

${ }^{5}$ Campus de Ciências Exatas e Tecnológicas Henrique Santillo - CCET, Universidade Estadual de Goiás - UEG, BR-153, 3105, CEP 75132-903, Anápolis, GO, Brasil

*e-mail: joao.nabout@ueg.br

Cite as: Alves, M.T.R. et al. A snapshot of the limnological features in tropical floodplain lakes: the relative influence of climate and land use. Acta Limnologica Brasiliensia, 2019, vol. 31, e10.

Abstract: Aim: This study aimed to investigate the relative influence of climate (temperature and precipitation) and land use on limnological features of 30 floodplain lakes in the Araguaia River, in Central Brazil, an important river that drains in the Brazilian Cerrado. Methods: The lakes were sampled in one same period, at a large spatial scale ( $900 \mathrm{~km}$ along the river) covering climate and landscape variability. For decomposing the relative importance of land use and climate, we used the RDA and partitioning variance techniques. Results: The lakes presented limnological gradient along the floodplain; in general, the lakes presented low transparency, nutrients concentrations (total nitrogen and total phosphorus) and oxygen saturation. The water $\mathrm{pH}$ was considered weakly acidic. Considering land use in Araguaia river basin, lakes in downstream presented more remnant vegetation and lakes in upstream presented more livestock and agriculture soil use. The climate conditions were the most important in explaining the variation in limnological characteristics of the lakes, while the individual analysis of limnological variables showed that land use was important to explain to the $\mathrm{pH}$ and transparency of the water. Conclusions: Finally, this study showed the importance of investigating regional climatic attributes and land use information to explain the limnological characterization of floodplain lakes. Thus, it highlights the importance of the possible impacts of global climate change on limnological conditions.

Keywords: Araguaia floodplain; RDAp; water quality; Cerrado.

Resumo: Objetivo: O objetivo desse estudo foi investigar a influência relativa do clima (temperatura e precipitaçáo) e do uso da terra nas características limnológicas de 30 lagoas da planície de inundação do Rio Araguaia, no Brasil Central, um importante rio que drena no Cerrado brasileiro. 
Métodos: As lagoas foram amostradas em um mesmo período, em uma grande extensão espacial (900 km ao longo do rio) cobrindo uma variabilidade climática e de paisagem. Para decompor o efeito relativo do clima e do uso do solo foi utilizada uma RDA seguida da partição da variância. Resultados: As lagoas apresentaram um gradiente limnológico ao longo da planície de inundação. Em geral, as lagoas possuem baixa transparência, concentração de nutrientes (nitrogênio total e fósforo total) e saturação de oxigênio. $\mathrm{O} \mathrm{pH}$ da água pode ser considerado fracamente ácido. Considerando o uso do solo na bacia do Rio Araguaia, as lagoas a jusante da planície apresentaram maior percentual de vegetaçáo remanescente, ao passo que lagoas a montante da planície apresentaram maior uso do solo em pastagem em agricultura. As características climáticas foram o principal fator para explicar a variação das características limnológicas das lagoas estudadas, enquanto que análises individuais das variáveis limnológicas evidenciaram que o uso do solo foi importante para explicar a variação no $\mathrm{pH}$ e transparência da água. Conclusóes: $\mathrm{O}$ presente estudo evidenciou a importância de investigar os atributos climáticos regionais e o uso do solo para explicar as características limnológicas de lagoas na planície de inundação. Portanto, destacamos a importância de possíveis impactos das mudanças climáticas globais sobre as características limnológicas.

Palavras-chave: planície de inundação do Araguaia; RDAp; qualidade de água; Cerrado.

\section{Introduction}

Limnological variables, such as $\mathrm{pH}$, dissolved oxygen, turbidity, nutrient concentrations, among others, have often been used to describe the quality of aquatic environments (Nabout et al., 2006) and as predictors of biological communities (Nabout et al., 2009; Bottino et al., 2013; Hortal et al. 2014; Gurgel-Lourenço et al., 2015; Arrieira et al., 2015). Technological advances (e.g., limnological probes) and the costs reductions of various equipments have allowed researchers to collect several reliable and efficient environmental information, besides to expand their studies spatially and temporally.

The lake environmental characteristics, often used by limnologists, may change along time, due climatic (e.g., Tonolla et al., 2010; Gray et al., 2011) and hydrological variation (Pithart et al., 2007) or changes in land use (Hudson et al., 2006; Jordan et al., 2012). The climate is a factor that has been extensively studied in aquatic environments research, and has been indicated as determinant in regional scales (Yue et al., 2011). The climate is marked by two variables that influence intrinsically ecosystems: the temperature and seasonal changes due to rainfall. The air temperature is directly related to the water temperature, which in turn is directly involved in chemical reactions that happens in aquatic environments, affect the water mixture and thermal stratification (Adrian et al., 2009) and influence the dispersion of species (e.g., Beesley et al., 2012; Tonolla et al., 2012). In addition, these physical and chemical variables may be affected by global climate change (Barros et al., 2011; Vörösmarty et al., 2010; Ye et al., 2013). Therefore, it is important to investigate the contribution of regional climate variables on limnology features, especially given the scarcity of studies focusing on climate change and limnology (Nabout et al., 2012) and floodplains systems in South America (Junk, 2013).

The land use and anthropogenic changes are also factors that directly influence the maintenance of water resources. Overall, impacted environments (e.g., converted land use for agriculture), promotes greater flow of allochthonous material, altering the nitrogen and phosphorus concentrations (Harmel et al., 2006) and changes in the landscape, such as erosion and sedimentation (Latrubesse et al., 2009; Valente et al., 2013). Material from erosion can reduce transparency and chlorophyll-a while the input of fertilizers into water promotes an increase in nutrients concentrations (Teffera et al., 2017).

These factors (i.e., climate and land use) are widely used to explain the temporal variation of limnological attributes. For example, in dry season is expected to lakes of a floodplain a greater transparency than in the rainy season (Thomaz et al., 2007) due to the lower amount of suspended solids and turbidity during the dry and that can be intensified with the inflow of water during the flood. Nevertheless, little is known about the causes of spatial variation of limnological attributes among different lentic ecosystems. Sampling snapshot in large spatial scale is useful to investigate the spatial variation of limnological attributes. Limnological studies in regional spatial scale has increased over the years (see Nabout et al., 2015), which provides insight in the same temporal interval, into how the limnological variables respond to climate and land use changes.

Thus, this study investigated the relative importance of climate variables (temperature and precipitation) and land cover using a snapshot 
sampling in large spatial scale, in one important aquatic system of Central Brazil (Araguaia River). More specifically, we investigate (i). Which factors (climatic and land use) promote a spatial variation of limnological variables; (ii). The influence of most important tributary of Araguaia River (Mortes River) on limnological features of the lakes. We expect that climatic factors and land use influence the lakes limnological variables, and sites with a higher level of anthropization should have deteriorated limnological conditions. On the other hand, we expect distinct limnological conditions between the lakes located above and below river of Mortes, since the input of water of this tributary, may alter the conditions of the downstream lakes.

\section{Methods}

\subsection{Study area}

The Araguaia River is inserted in the large Tocantins-Araguaia basin, one of the largest watershed in Brazil. This basin presents the highest diversity of plants in the continent, with significant ecotone area between Brazilian Cerrado (savanna) and the Amazon forest biomes (Latrubesse \& Steveaux, 2006; Morais et al., 2005; Sawakuchi et al., 2013). Tocantins - Araguaia basin drains rivers of several Brazilian States, with an area of $377,000 \mathrm{~km}^{2}$ (Morais et al., 2005). The middle course of Araguaia
River, where is situate the study area, stretches over $1100 \mathrm{~km}$, between the municipalities Barra do Garça and Conceição do Araguaia, and homes a well-developed floodplain, including the alluvial plain of Bananal (Valente et al., 2013; Latrubesse \& Steveaux, 2002). In the meantime, the drainage area increases due to the tributaries increase, where the Mortes River is the most important (Latrubesse \& Steveaux, 2006). The climate presents semi-humid with humid trend, characterized according Kopen as Aw type (Latrubesse \& Steveaux, 2002). It is a region marked by two well-defined seasons, rainy and dry, due the influence of Cerrado biome region. The rainy is between the months of November and April, and dry between May and August, with an average annual temperature of $22{ }^{\circ} \mathrm{C}$, and average maximum of $28^{\circ} \mathrm{C}$ (Latrubesse \& Steveaux, 2006).

For limnological analysis were selected 30 lakes along the floodplain system in the Araguaia River (Figure 1), Central Brazil (see also Machado et al., 2015). The lakes were selected in order to capture a gradient of environmental variation (i.e., lakes preserved and impacted) along the floodplain. The straight-line distance between the floodplain lakes was $500 \mathrm{~km}$ (and about $900 \mathrm{~km}$ along the river course). The lakes are shallow (4.2-9.6 meters of depth) whit average area of $0.70 \mathrm{~km}(0.007-3.60 \mathrm{~km}$, see more details in Marcionilio et al., 2016). The Araguaia

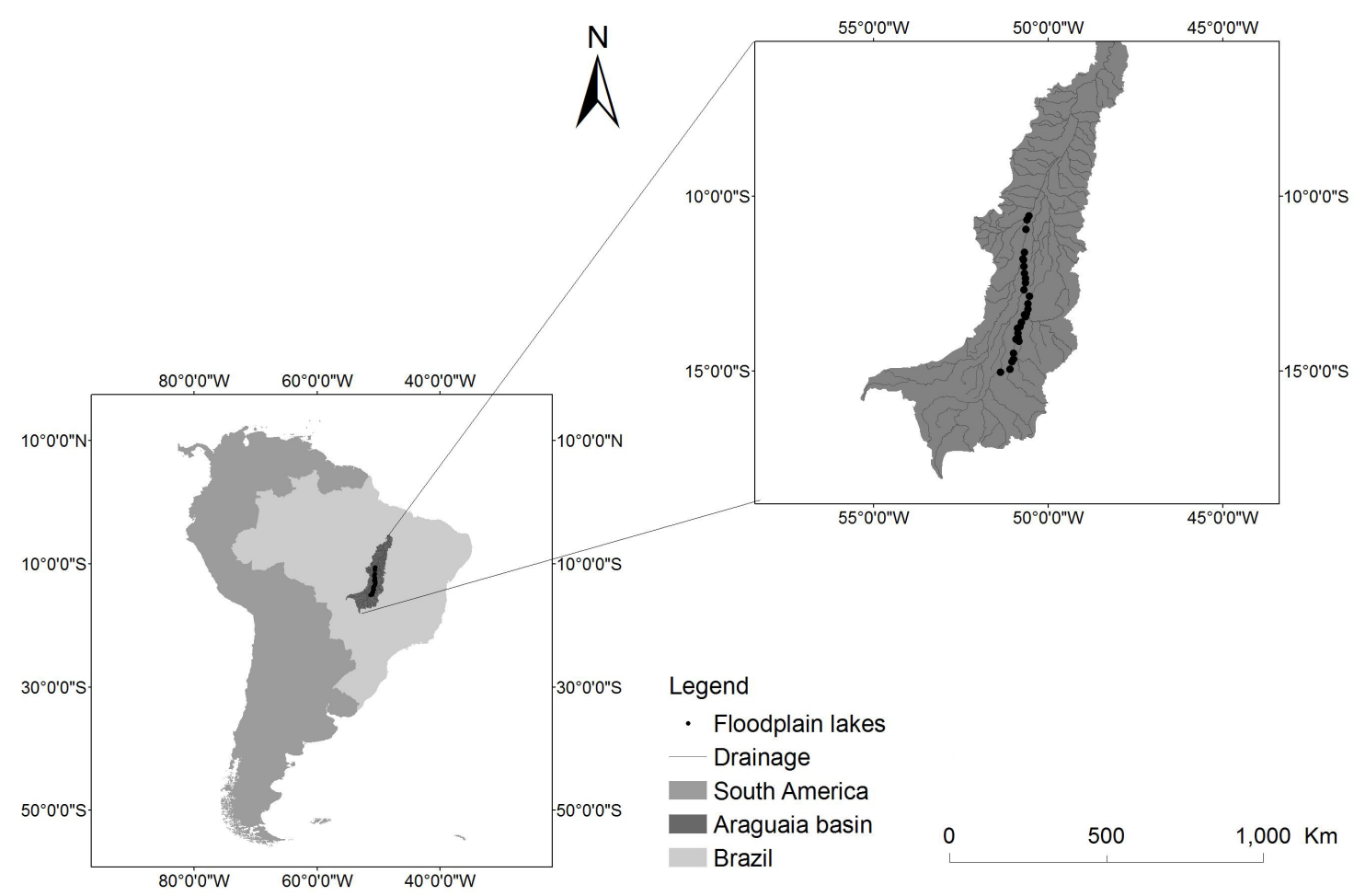

Figure 1. Location of the Tocantins-Araguaia river basin, highlighting the sampling points used in this study. 
River alluvial plain has four predominant types of vegetation: herbaceous, shrubby - arboreal, arboreal and anthropogenic vegetation (Latrubesse $\&$ Steveaux, 2006). Most of the lakes sampled are surrounded by Cerrado native vegetation, but some have undergone conversion in the land use, with substitution of vegetation native by agriculture and livestock (see Machado et al., 2016).

\subsection{Limnological variables}

The samples were carried out from high water (January 2012). This period was chosen because it allows a better access to the lakes, since all were connected to the main channel of the river, reducing the costs associated with sampling in this wide spatial scale. Thus, in this study, we demonstrate a view of the limnological variables for the Araguaia River floodplain in a single climatic period. The variables collected were: conductivity $(\mu S / \mathrm{cm})$, $\mathrm{pH}$, oxygen saturation $(\%)$, water temperature $\left({ }^{\circ} \mathrm{C}\right)$, transparency $(\mathrm{cm})$, total phosphorus $(\mu \mathrm{g} / \mathrm{L})$, and total nitrogen $(\mu \mathrm{g} / \mathrm{L})$. For the analysis of nutrients, samples were collected and stored in accordance with the American Public Health American (APHA) specifications (APHA, 1999). The water transparence was obtained using a Secchi disk and others variables using a portable probes (Digimed). The parameters were estimated and the nutrient samples collected at a central point of the lake at a depth of $0.5 \mathrm{~m}$. The geographic coordinates of the lakes were obtained using a Global Navigation Satellite System (GNSS) device (Garmim).

\subsection{Land use and human impact variables}

The land use around the lakes (Cerrado remnant vegetation, livestock and agriculture), was obtained using satellite image classification (Landsat 5 - TM 2011 imagery, and Google Earth available-high-resolution data set). We used the Landsat 5 - TM collection (with $30 \mathrm{~m}$ spatial resolution), path/row 223/67 to 223/70, from May 2011 (flood period in the Araguaia River), with low cloudiness. Data were available from the National Institute for Space Research (INPE, 2012). A geometric correction of the satellite images was performed by comparison to Geocover project data set (USGS, 2012), resulting in an image mosaic for the entire study area (referring to May 2011). The analysis of the land use was limited to the lakes surrounding, with a buffer of $10 \mathrm{~km}$.

In terms of image processing, we applied a Linear Spectral Mixture Model algorithm to process the Landsat mosaic, highlighting the land use land cover classes (see algorithm for Cerrado biome in Ferreira et al., 2007), followed by a MaxVer supervised classification algorithm (this method employs training pixels for each land use classes).

It was also obtained the anthropization data for each lake through Grid Human Footprint (Sanderson et al., 2002). This grid presents human impact values for each geographic coordinate based on several factors of human action, such as population density, land use, infrastructure, possibility of human access, etc. The Grid was obtained through the site SEDAC (SEDAC, 2012) and has a resolution of $1 \mathrm{~km}$ (Sanderson et al., 2002). Therefore for each lake it was assigned a value of Human Footprint, ranging from zero (no impact) to 1 (maximum impact).

\subsection{Climate variables}

To characterize the climate of each lake, we obtained the data of nineteen (19) bioclimatic variables related to temperature and rainfall in the study area. These climate variables were obtained in a world database available in Worldclim website (Worldclim, 2012), using a grid with a resolution of $4 \mathrm{~km}$. These variables represent the precipitation and temperature variations recorded in the investigated lakes. To obtain the climatic variables of each lake, the geographic coordinate of the lakes was overlapped on the grid with climatic data.

\subsection{Data analysis}

We performed a Principal Component Analysis (PCA) using the correlation matrix for limnological, climate and land use data set separately. The purpose of this analysis is reduce the dimensionality of multivariate data, generating new orthogonal variables (principal components) created from linear combinations of the original variables (Legendre \& Legendre, 2012) The first and second principal component for PCA of limnological data was used to assess the differences between the lakes located upstream and downstream of Mortes river. The first principal component for limnological, climate and land use PCA were plotted in the map, seeking to evaluate the spatial variation of these variables along the floodplain.

The partial redundancy analysis (RDAp) was used to obtain unique importance of each predictor for limnological characteristics. Two sets of predictors were used: i) climatic variables, corresponding to the first three axes of the PCA for bioclimatic variables (representing $89 \%$ of variation in the climate data); ii) Land use, corresponding 
to the first three axes of the PCA for percentage of remaining vegetation, agriculture, pasture and Human Footprint index (representing 96\% of variation in the land use data). The response variable was the limnological variables. New RDAp were performed to assess the importance of predictors in which each limnological variable individually. Partial components of RDA were: [a] the variation explained purely by the climate, $[\mathrm{b}]$ shared variation between climate and land use, $[c]$ purely variation explained by land use, [d] residual variation.

Among the main assumptions of the RDA, it highlights the need for independence of the sampling unit (i.e., lakes), which can be measured by assessing the spatial structure in the residual of RDA. The existence of spatial autocorrelation can perturb significance tests, promoting inflated type I error (see Legendre, 1993; Diniz-Filho et al., 2003). Thus, after each RDAp, spatial autocorrelation of the residual was investigated. For this a new RDAp, in which the residual was the dependent variable, and the spatial filter was the explanatory variable. Geographic coordinates were used to generate the spatial filters using PCNM (Principal coordinate of neighbor matrices) (Griffith \& Peres-Neto, 2006; Nabout et al., 2009). No significant values indicate that there was no spatial autocorrelation in the residual, thus there was no flaw in the assumption of independence of the sample units.

For all analysis (PCA, RDAp and partitioning the variance), all variables were previously transformed. The limnological data were log-transformed $(\log \mathrm{X}+1)$, except the $\mathrm{pH}$. For the climate data was used the $\mathrm{z}$-score transformation, and for the land use data and human footprint (both given in percentage) was used the transformation arcsine square root $\left(\operatorname{asin}(\operatorname{sqrt}(\mathrm{x}))^{*} 180 / \mathrm{pi}\right)$. All analysis were performed in the R program (Core Team R, 2016) using Vegan package (Oksanen et al., 2015).

\section{Results}

The lakes in Araguaia River revealed weakly acidic environments, with typical temperature of tropical environments, moderate oxygen saturation, low transparency and low nutrient values (Table 1). However, along the $900 \mathrm{~km}$ gradient it was possible to observe a variation of the limnological features among the lakes studied (Figure 2 and 3). The principal component analysis for limnological characteristics revealed that the first two axes explained $69.1 \%$ of the variance of the data. The downstream lakes located after confluence of Mortes river, showed higher

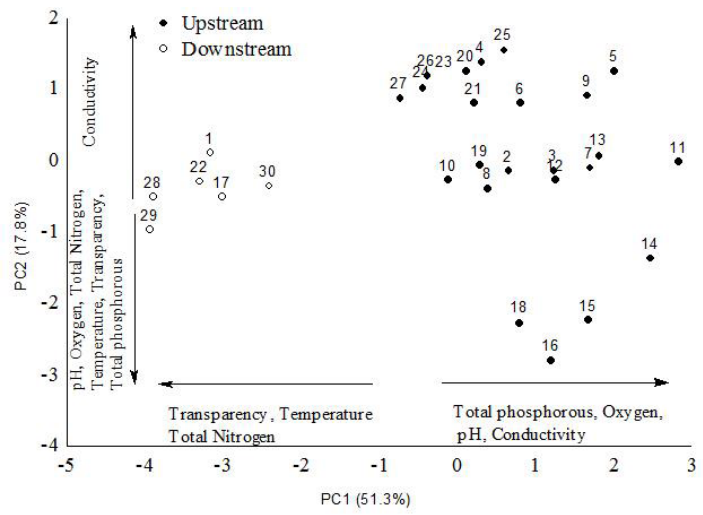

Figure 2. Principal Component Analysis (PCA) of the limnological variables for thirty floodplain lakes of the Araguaia River.

temperature and with a higher concentration of total nitrogen and greater transparency, suggesting that these limnological environment are different from others (i.e., upstream of Mortes river) floodplain lakes. The limnological, climate and land use variables exhibit spatial variation (Figure 3, Table 1). Positive values for the first axis of PCA indicate lakes with greater seasonality precipitation in driest month. The negative values indicate lakes in areas with higher isothermality and higher annual precipitation. As for the land use, the first component separates the preserved and impacted environment (pasture and human footprint). Thus, negative values indicate preserved lakes, while positive values indicate impacted lakes.

The RDAp revealed that $26 \%$ of the spatial variation in limnological variables were explained by the land use and climate variables (Figure 4). Furthermore, the partial component revealed that climate variables (component $a, \mathrm{R}^{2}=0.19$, $P=0.007)$ were more important in explaining the limnological characteristics of the floodplain lakes (Figure 4). The variation of the limnological variables conductivity, transparency, oxygen saturation, total phosphorus and total nitrogen, was explained by climate variables (Table 2). However, $\mathrm{pH}$ and transparency were explained significantly by characteristic of land use around the lakes. For all RDAp were not found spatial structure in residual.

\section{Discussion}

The features of the limnological variables are important to understand the environmental quality and the maintenance of aquatic biodiversity (Espejo et al., 2012). These characteristics are affected 


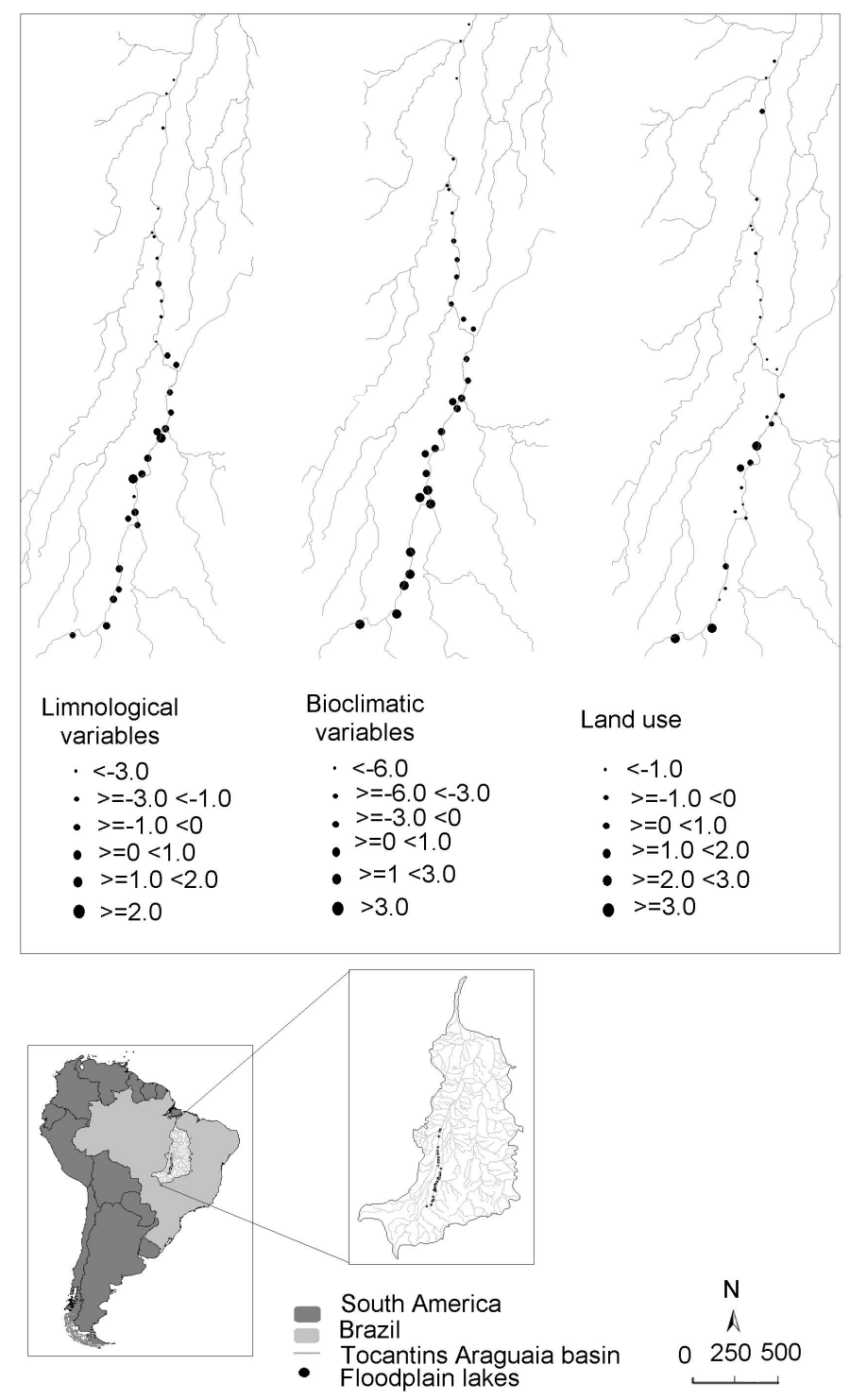

Figure 3. Spatial variation of limnological, climate and land use variables along the Araguaia River. These maps were constructed using the first principal component of principal component analysis.

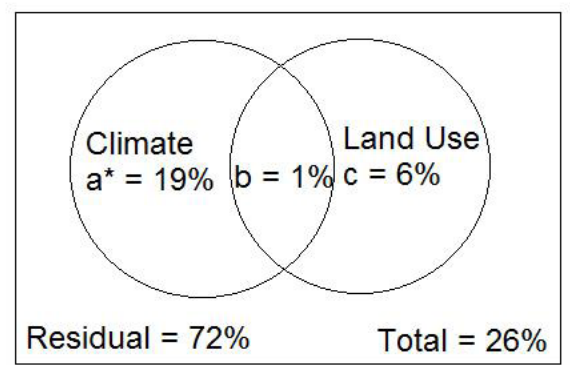

Figure 4. Diagram showing the importance of climate and land use to explain the limnological characteristics of floodplain lakes of the Araguaia River. The partial component: (a) purely climate, (b) shared between climate and land use, (c) purely land use, and (d) Residual. * Indicates significant $\mathrm{P}$ values $<0.05$. For this model the residual not showed spatial autocorrelation $(\mathrm{P}=0.44)$. by internal factors (autochthonous) and marginal factors to aquatic ecosystems (allochthonous). Therefore, climatic variables and land use changes in the surrounding of aquatic environment can affect its limnological characteristics. In the present study the climatic variables were most important to explain the limnological characteristics. However, for some limnological variables (such as $\mathrm{pH}$ and transparency), land use category also demonstrated to be an important factor for this aquatic environment. Thus, in a regional scale (as of this study), it is important to a joint analysis of climate variables and land use to understand the spatial dynamics of limnological features of floodplain lakes. 
Table 1. Statistical summary for the limnological, land use and bioclimate variables of the sampled lakes.

\begin{tabular}{|c|c|c|c|}
\hline & Mean( $( \pm s d)$ & Minimum & Maximum \\
\hline \multicolumn{4}{|l|}{ Limnological features } \\
\hline $\mathrm{pH}$ & $6.5( \pm 0.47)$ & 5.9 & 7.8 \\
\hline Electrical conductivity $(\mathrm{mS} / \mathrm{cm})$ & $177.7( \pm 144.3)$ & 12.7 & 448 \\
\hline Temperature $\left({ }^{\circ} \mathrm{C}\right)$ & $28( \pm 1.38)$ & 24.6 & 31.1 \\
\hline Oxygen Saturation (\%) & $20( \pm 9.49)$ & 6.4 & 45.3 \\
\hline Total Phosphorous ( $\mu \mathrm{g} / \mathrm{L})$ & $16.1( \pm 6.41)$ & 4.6 & 31.1 \\
\hline Total Nitrogen $(\mu \mathrm{g} / \mathrm{L})$ & $720.0( \pm 280)$ & 180 & 1480 \\
\hline Transparency $(\mathrm{cm})$ & $84( \pm 58)$ & 19 & 223 \\
\hline \multicolumn{4}{|l|}{ Land use features } \\
\hline Native Vegetation (\%) & $74.1( \pm 25)$ & 9.2 & 90 \\
\hline Pasture (\%) & $12.7( \pm 23.12)$ & 0 & 8.7 \\
\hline Agriculture (\%) & $4.3( \pm 10.9)$ & 0 & 51.7 \\
\hline Human foot print (ha.) & $19.4( \pm 5.93)$ & 14.1 & 35.6 \\
\hline \multicolumn{4}{|l|}{ Bioclimatic variables } \\
\hline $\mathrm{BIO} 1$ & $26.7( \pm 0.48)$ & 25.9 & 27.5 \\
\hline $\mathrm{BIO} 2$ & $11.8( \pm 0.15)$ & 11.6 & 12.3 \\
\hline $\mathrm{BIO} 3$ & $72.3( \pm 1.53)$ & 70.2 & 75.5 \\
\hline $\mathrm{BlO} 4$ & $85.6( \pm 8.63)$ & 60.4 & 103.1 \\
\hline $\mathrm{BIO} 5$ & $34.4( \pm 0.45)$ & 33.6 & 35.1 \\
\hline $\mathrm{BlO} 6$ & $17.9( \pm 0.64)$ & 16.6 & 19 \\
\hline $\mathrm{BlO} 7$ & $16.4( \pm 0.22)$ & 15.9 & 17 \\
\hline $\mathrm{BIO} 8$ & $27.2( \pm 0.53)$ & 26.4 & 28.1 \\
\hline $\mathrm{BlO9}$ & $25.7( \pm 0.48)$ & 24.7 & 26.5 \\
\hline $\mathrm{BIO10}$ & $27.5( \pm 0.41)$ & 26.8 & 28.2 \\
\hline BIO11 & $25.4( \pm 0.61)$ & 24.3 & 26.4 \\
\hline $\mathrm{BIO} 12$ & $1644.8( \pm 90.1)$ & 154 & 1847 \\
\hline $\mathrm{BIO} 13$ & $298.4( \pm 16.76)$ & 280 & 344 \\
\hline $\mathrm{BIO} 14$ & $3.6( \pm 0.85)$ & 2 & 5 \\
\hline $\mathrm{BIO15}$ & $85.5( \pm 1.58)$ & 81.3 & 87.6 \\
\hline $\mathrm{BIO} 16$ & $836.9( \pm 36.27)$ & 788 & 947 \\
\hline $\mathrm{BIO} 17$ & $18.3( \pm 2.33)$ & 15 & 24 \\
\hline $\mathrm{BIO18}$ & $410.5( \pm 17.48)$ & 382 & 451 \\
\hline $\mathrm{BIO} 19$ & $39.1( \pm 3.32)$ & 34 & 50 \\
\hline
\end{tabular}

BIO1 = Annual Mean Temperature; BIO2 = Mean Diurnal Range (Mean of monthly (max temp - min temp)); BIO3 = Isothermality $(\mathrm{BIO} 2 / \mathrm{BIO} 7)\left({ }^{*} 100\right) ; \mathrm{BIO} 4=$ Temperature Seasonality (standard deviation *100); BIO5 = Max Temperature of Warmest Month; BIO6 = Min Temperature of Coldest Month; BIO7 = Temperature Annual Range (BIO5-BIO6); BIO8 = Mean Temperature of Wettest Quarter; BIO9 = Mean Temperature of Driest Quarter; BIO10 = Mean Temperature of Warmest Quarter; BIO11 = Mean Temperature of Coldest Quarter; BIO12 = Annual Precipitation; BIO13 = Precipitation of Wettest Month; BIO14 = Precipitation of Driest Month; BIO15 = Precipitation Seasonality (Coefficient of Variation); BIO16 = Precipitation of Wettest Quarter; BIO17 = Precipitation of Driest Quarter; BIO18 = Precipitation of Warmest Quarter; BIO19 = Precipitation of Coldest Quarter.

Table 2. The importance relative (measured by $\mathrm{R}^{2}$ ) of climate and land use for each individual limnological variable. Partial components are (a) purely climate, (b) shared between climate and land use, (c) purely land use, and (d) residual. Numbers in boldface indicate $\mathrm{P}<0.05$. The significance for the $\mathrm{b}$ and $\mathrm{d}$ components cannot be tested. No spatial autocorrelation in residual of regressions was found ( $P$ values greater than 0.05$)$.

\begin{tabular}{lcccc}
\hline & $\begin{array}{c}\text { Climate } \\
(\mathbf{a})\end{array}$ & $\begin{array}{c}\text { Climate + land use } \\
\text { (b) }\end{array}$ & $\begin{array}{c}\text { Land use } \\
\text { (c) }\end{array}$ & $\begin{array}{c}\text { Residuals } \\
\text { (d) }\end{array}$ \\
\hline Conductivity & $\mathbf{0 . 2 4}$ & -0.06 & -0.04 & 0.86 \\
$\mathrm{pH}$ & -0.05 & 0.09 & $\mathbf{0 . 2 0}$ & 0.70 \\
Temperature & 0.10 & 0.09 & 0.09 & 0.70 \\
Transparency & $\mathbf{0 . 3 9}$ & -0.01 & $\mathbf{0 . 1 4}$ & 0.47 \\
Oxygen Saturation & $\mathbf{0 . 3 5}$ & 0.15 & 0.002 & 0.48 \\
Total Phosphorous & $\mathbf{0 . 4 2}$ & 0.16 & -0.04 & 0.44 \\
Total nitrogen & $\mathbf{0 . 3 4}$ & -0.02 & 0.06 & 0.60 \\
\hline
\end{tabular}


The 30 lakes studied in this paper are perennial and had the typical characteristics of water quality for flood seasons. According Brazilian legislation (CONAMA resolution 357/05) the limnological features of the lakes, with the exception of oxygen saturation, showed good water quality and good preservation of the lakes. In addition, the limnological characteristics of this study were different from data for the years 2000 and 2001 using other lakes in the rainy and dry season (Nabout et al., 2006; Nabout et al., 2007). Here, the lakes showed higher concentrations of nutrients and less oxygen saturation, when compared to a previous study carried out in the rainy season (Nabout et al., 2006). That is, although currently lakes are preserved, a comparison with other older studies reveal changes in limnological characteristics, indicating increased level of anthropogenic impact on the lakes to the Araguaia river.

The bioclimatic variables are represented by temperature and precipitation values over the months or years (Hijmans et al., 2005). Thus, they reflect the variation that these parameters can present in a region. In this study, climatic variables were important to explain the limnological parameters and the climate was directly associated with conductivity, transparency, oxygen saturation, phosphorus and total nitrogen. In fact, the air temperature acts on aquatic ecosystems in a variety of ways influencing, for example, the stratification levels in the water column and physicochemical parameters, such as oxygen and nutrient concentrations (Adrian et al., 2009). The intensity of winds (a factor not considered in this study) also represents a relevant climatic variable. In floodplain lakes, the winds seem to be more important during the dry season, influencing the sediments resuspension according to the lake morphometry, besides providing a greater variation in the chemical, physical and biological characteristics during this period (Thomaz et al., 2007). For floodplain lakes, precipitation may be even more relevant, since it influences the hydrological levels of the plain, controlling the flood and flow periods and consequently affecting the limnological variables (Junk et al., 1989). In our study, precipitation is apparently the most important factor as we did our sampling during the rainy season, a period when winds are lower than the dry season and also the effects of temperature on water stratification are not occurring.

Although this study has evaluated the effects of climate at present, the influence of climate change on limnological variables has already been projected for the future. Studies have shown that the temperature increase can reduce the amount of oxygen available in the water (McKee et al., 2003; Feuchtmayer et al., 2009; Jeppesen et al., 2010) and increase the nutrients resuspension present in the sediments (Jeppesen et al., 2010).

The importance of climate on the limnological variables highlights the importance of global climate change on regional limnological conditions. Indeed, much has been discussed about the impact of climate change at different geographical scales; however, it still require studies to assess the impact of climate change on aquatic environments (Nabout et al., 2012). For the Cerrado region, in addition to the increase in temperature forecast, is expected change in the hydrological cycle, promoting an increase in extreme events such as greater period of drought and rainfall concentrated in short time (Bustamante et al., 2012). Thus, these changes should affect the limnological structure of the lakes studied, caused loss of environmental quality, eutrophication and consequent threat for aquatic biodiversity (Hall et al., 2008).

In addition to climate change, an important phenomenon that has occurred mainly in Central Brazil is the intensive conversion of native vegetation in agro-pastoral activities in floodplain areas (Middleton, 2002; Latrubesse \& Steveaux, 2006; Tonolla et al., 2010). The great loss of flood areas in different countries and in different ecosystems raises concerning about the remaining areas and studies for the maintenance of these environments (Steven \& Gramling, 2012; Van Den Brink et al., 2013; Schleupper \& Schneider, 2013), especially when a significant area is occupied by commodities like soybeans or pasture, as occurred in Cerrado bioma (Lapola et al., 2013).

Extensive floodplains have been lost during the agricultural areas expansion process and the creation of large areas of urbanization (Brinson $\&$ Malvárez, 2002). The present floodplain lakes had low anthropogenic conversion rate. Twelve lakes have been modified to land use, mainly in the state of Goiás and Mato Grosso (significant parcel of Cerrado). Mostly the lakes in Tocantins state are best preserved. These lakes are close by indigenous areas and Bananal Island conservation unity, enabling greater protection of natural resources in the region (Sawakuchi et al., 2013). In addition, Tocantins has until this moment less deforestation rate, being one of the most preserved area in this study (Sano et al., 2010). 
Finally, this study showed the importance of investigating regional climatic attributes and land use information to explain the limnological characterization of floodplain lakes. In general, climate variables were most important to explain the limnological characteristics of the studied lakes. Thus, it highlights the importance of the possible impacts of global climate change on regional and local limnological conditions. Besides, changes in land use and increase of impacted areas could also affect the limnological characteristics of the floodplain lakes of the Araguaia River.

\section{Acknowledgements}

MTRA and KBM received a scholarship from Fundação de Amparo à Pesquisa do Estado de Goiás (FAPEG) and Coordenação de Aperfeiçoamento de Pessoal de Nível Superior (CAPES), respectively. Our work on aquatic science and land use change have been continuously supported by different grants: Conselho Nacional de Desenvolvimento Científico e Tecnológico (CNPq) (project no 563834/2010-2), FAPEG (projects no 201212267001071 and 201210267000966), CAPES (AUXPE 2036/2013) and and National Institutes for Science and Technology (INCT) in Ecology, Evolution and Biodiversity Conservation. MEF and JCN were supported by CNPq productivity fellowships.

\section{References}

ADRIAN, R., O'REILLY, C.M., ZAGARESE, H., BAINES, S.B., HESSEN, D.O., KELLER, W., LIVINGSTONE, D.M., SOMMARUGA, R., STRAILE, D., VAN DONK, E., WEYHENMEYER, G.A. and WINDER, M. Lakes as sentinels of climate change. Limnology and Oceanography, 2009, 54(6), 2283-2297. http://dx.doi.org/10.4319/ lo.2009.54.6_part_2.2283. PMid:20396409.

AMERICAN PUBLIC HEALTH ASSOCIATION APHA. Standard Methods for the examination of water and wastewater. Washington: APHA/WEF/AWWA, 1999, $1400 \mathrm{p}$.

ARRIEIRA, R.L., ALVES, G.M., SCHWIND, L.T. and LANSAC-TÔHA, F.A. Local factors affecting the testate amoeba community (Protozoa: Arcellinida; Euglyphida) in a neotropical floodplain. Journal of Limnology, 2015, 74(3), 444-452.

BARROS, N., COLE, J.J., TRANVIK, L.J., PRAIRIE, Y.T., BASTVIKEN, D., HUSZAR, V.L.M., DEL GIORGIO, P. and ROLAND, F. Carbon emission from hydroelectric reservoirs. Nature Geoscience, 2011, 4(9), 593-596. http://dx.doi.org/10.1038/ ngeo 1211 .
BEESLEY, L., KING, A.J., AMTSTAETTER, F., KOEHN, J.D., GAWNE, B., PRICE, A., NIELSEN, D.L., VILIZZI, L. and MEREDITH, S.N. Does flooding effect spatiotemporal variation of fish assemblages in temperature floodplain wetlands? Freshwater Biology, 2012, 57(11), 2230-2246. http:// dx.doi.org/10.1111/j.1365-2427.2012.02865.x.

BOTTINO, F., CALIJURI, M.C. and MURPHY, K.J. Temporal and spatial variation of limnological variables and biomass of different macrophyte species in a Neotropical reservoir (São Paulo - Brazil). Acta Limnologica Brasiliensia, 2013, 25(4), 387-397. http://dx.doi.org/10.1590/S2179975Х2013000400004.

BRINSON, M.M. and MALVARÉZ, I. Temperature freshwater wetlands: Types, status and threats. Environmental Conservation, 2002, 29(2), 115-133. http://dx.doi.org/10.1017/S0376892902000085.

BUSTAMANTE, M.M.C., NARDOTO, G.B., PINTO, A.S., RESENDE, J.C.F., TAKAHASHI, F.S.C. and VIEIRA, L.C.G. Potential impacts of climate change on biogeochemical functioning of Cerrado ecosystems. Brazilian Journal of Biology, 2012, 72(3), 655-671, Supplement. PMid:23011296.

CORE TEAM R. R: A language and environmental for statistical computing [online]. Vienna: R Foundation for Statistical Computing, 2016 [viewed 15 Sep. 2017]. Available from: http://www.R-project.org/

DINIZ-FILHO, J.A.F., BINI, L.M. and HAWKINS, B.A. Spatial autocorrelation and red herrings in geographical ecology. Global Ecology and Biogeography, 2003, 12(1), 53-64. http://dx.doi.org/10.1046/ j.1466-822X.2003.00322.x.

ESPEJO, L., KRETSCHMER, N., OYARZÚN, J., MEZA, F., NÚNEZZ, J., MATURANA, H., SOTO, G., OYARZO, P., GARRIDO, M., SUCKEL, F., AMEZAGA, J. and OYARZÚN, R. Application of water quality indices and analysis of the surface water quality monitoring network in semiarid North - Central, Chile. Environmental Monitoring and Assessment, 2012, 184(9), 5571-5588. http://dx.doi. org/10.1007/s10661-011-2363-5. PMid:21938385.

FERREIRA, M.E., FERREIRA, L.G., SANO, E.E. and SHIMABUKURO, Y.E. Spectral linear mixture modelling approaches for land cover mapping of tropical savanna areas in Brazil. International Journal of Remote Sensing, 2007, 28(2), 413-429. http:// dx.doi.org/10.1080/01431160500181507.

FEUCHTMAYER, H., MORAN, R., HATTON, K., CONNOR, L., HEYES, T., MOSS, B., HARVEY, I. and ATKINSON, D. Global warming and eutrophication: effects on water chemistry and autotrophic communities in experimental hypertrophic shallow lake mesocosms. Journal of Applied Ecology, 2009, 46(3), 713-723. http://dx.doi. org/10.1111/j.1365-2664.2009.01644.x. 
GLOBAL CLIMATE DATA - WORLDCLIM. [online]. United States: Worldclim, 2012 [viewed 20 Sep. 2012]. Available from: http://www.worldclim.org/ current/

GRAY, B.R., ROGALA, J.R. and HOUSER, J.N. Treating foodplain lakes of larges rivers as study units for variables that vary within lakes; an evaluation using Clorophill-A and Inorganic suspended solids data from floodplain lakes of the upper Mississippi river. River Research and Applications, 2011, 29(3), 330-342. http://dx.doi.org/10.1002/rra.1603.

GRIFFITH, D.A. and PERES-NETO, P.R. Spatial modeling in ecology: the flexibility of eigenfunction spatia 1 analyses. Ecology, 2006, 87(10), 2603-2613. http://dx.doi.org/10.1890/00129658(2006)87[2603:SMIETF]2.0.CO;2. PMid: 17089668 .

GURGEL-LOURENCO, R.C., RODRIGUESFILHO, C.A.S., ANGELINI, R., GARCEZ, D.S. and SÁNCHEZ-BOTERO, J.I. On the relation amongst limnological factors and fish abundance in reservoirs at semiarid region. Acta Limnologica Brasiliensia, 2015, 27(1), 24-38. http://dx.doi. org/10.1590/S2179-975X2414.

HALL, N., STUNTZ, B. and ABRAMS, R. Climate change and freshwater resources. Natural Resources and Environment, 2008, 22, 30-35.

HARMEL, R.D., POTTER, S., CASEBOLT, P., RECKHOW, K., GREEN, C.H. and HANEY, R.L. Compilation of measured nutrient load data for agricultural land uses in the US. Journal of the American Water Resources Association, 2006, 42(5), 1163-1178. http://dx.doi.org/10.1111/j.1752-1688.2006. tb05604.x.

HIJMANS, R.J., CAMERON, S.E., PARRA, J.L., JONES, P.G. and JARVIS, A. Very high resolution interpolated climate surfaces for global land areas. International Journal of Climatology, 2005, 25(15), 1965-1978. http://dx.doi.org/10.1002/joc. 1276.

HORTAL, J., NABOUT, J.C., CALATAYUD, J., CARNEIRO, F.M., PADIAL, A., SANTOS, A.M.C., SIQUEIRA, T., BOKMA, F., BINI, L.M. and VENTURA, M. Perspectives on the use of lakes and ponds as model systems for macroecological research. Journal of Limnology, 2014, 73(s1,Suppl. Suppl.1), 46-60. http://dx.doi.org/10.4081/ jlimnol.2014.887.

HUDSON, P.F., COLDITZ, R.R. and AGUILARROBLEDO, M. Spatial relations between floodplain environmental and land use - land cover of a large low land tropical River Balley: Panuco Basin, México. Environmental Management, 2006, 38(3), 487-503. http://dx.doi.org/10.1007/s00267-003-0157-4. PMid: 16755357.

INSTITUTO NACIONAL DE PESQUISAS ESPACIAIS - INPE. [online]. São José dos Campos:
INPE, 2012 [viewed 05 May 2012]. Available from: http://www.dgi.inpe.br/CDSR

JEPPESEN, E., MOSS, B., BENNION, H., CARVALHO, L., DEMEESTER, L., FEUCHTMAYER, H., FRIBERG, N., GESSNER, M.O., HEFTING, M., LAURIDSEN, T.L., LIBORIUSSEN, L., MALMQUIST, L., MAY, H.J., MEERHOFF, M., OLAFSSON, J.S., SOONS, M.B. and VERHOEVEN, J.T.A. Interaction of climate change and eutrophication. In: $M$. KERNAN, R.W. BATTARBEE and B. MOSS Climate change impacts on freshwater ecosystems. New Jersey: Blackwell Publishing Ltd., 2010, pp. 120-151.

JORDAN, Y.C., GHULAM, A. and HERMAN, R.B. Floodplain ecosystems response to climate variability and land-cover and land-use change in Lower Missiori River Basin Lansdscape. Ecology, 2012, 27, 843-857.

JUNK, W., BAYLAY, P.B. and SPARKS, R.E. The flood pulse concept in river-floodplain systems. In: D.P. DODGE, ed. Proceedings of the international large river Symposium (LARS). Ottawa: Department of Fisheries and Oceans, 1989, pp. 110-127. Canadian Special Publication of Fisheries and Aquatic Sciences, 106.

JUNK, W.J. Current state of knowledge regarding South America wetlands and their future under global climate change. Aquatic Sciences, 2013, 75(1), 113131. http://dx.doi.org/10.1007/s00027-012-0253-8.

LAPOLA, D.M., MARTINELLI, L.A., PERES, C.A., OMETTO, J.P.H., FERREIRA, M.E., NOBRE, C.A., AGUIAR, A.P.D., BUSTAMANTE, M.M.C., CARDOSO, M.F., COSTA, M.H., JOLY, C.A., LEITE, C.C., MOUTINHO, P., SAMPAIO, G., STRASSBURG, B.B.N. and VIEIRA, I.C.G. Pervasive transition of the Brazilian land-use system. Nature Climate Change, 2013, 4(1), 27-35. http:// dx.doi.org/10.1038/nclimate2056.

LATRUBESSE, E. and STEVEAUX, J.C. Geomorphology and environmental aspects of Araguaia Fluvial Basin Brazil. Zeitschrift für Geomorphologie, 2002, 129, 109-127.

LATRUBESSE, E.M. and STEVEAUX, J.C. Características físico-bióticas e problemas ambientais associados à planície aluvial do Rio Araguaia, Brasil Central. Revista UNG- Geociências, 2006, 5(1), 65-73.

LATRUBESSE, E.M., AMSLER, M.L., MORAIS, R.P. and AQUINO, S. The geomorphologic response of a large pristine alluvial river the tremendous deforestation in the South American tropics: The case of the Araguaia River. Geomorphology, 2009, 113(3-4), 239-252. http://dx.doi.org/10.1016/j. geomorph.2009.03.014.

LEGENDRE, P. and LEGENDRE, L.F.J. Numerical ecology. 3rd ed. Amsterdam: Elsevier. 2012. vol. 24. 
LEGENDRE, P. Spatial autocorrelation: trouble or new paradigm? Ecology, 1993, 74(6), 1659-1673. http:// dx.doi.org/10.2307/1939924.

MACHADO, K.B., BORGES, P.P., CARNEIRO, F.M., SANTANA, J.F., VIEIRA, L.C.G., HUSZAR, V.L.M. and NABOUT, J.C. Using lower taxonomic resolution and ecological approaches as a surrogate for plankton species. Hydrobiologia, 2015, 743(1), 255 267. http://dx.doi.org/10.1007/s10750-014-2042-y.

MACHADO, K.B., TERESA, F.B., VIEIRA, L.C.G., HUSZAR, V.L.M. and NABOUT, J.C. Comparing the effects of landscape and local environmental variables on taxonomic and functional composition of phytoplankton communities. Journal of Plankton Research, 2016, 38(5), 1334-1346. http://dx.doi. org/10.1093/plankt/fbw062.

MARCIONILIO, S.M.L.O., MACHADO, K.B., CARNEIRO, F.M., FERREIRA, M.E., CARVALHO, P., VIEIRA, L.C.G., HUSZAR, V.L.M. and NABOUT, J.C. Environmental factors affecting chlorophyll-a concentration in tropical floodplain lakes, Central Brazil. Environmental Monitoring and Assessment, 2016, 188(11), 611-620. http://dx.doi.org/10.1007/s10661-016-5622-7. PMid:27726089.

MCKEE, D., ATKINSON, D., COLLINGS, S.E., EATON, J.W., GILL, A.B., HARVEY, I., HATTON, K., HEYES, T., WILSON, D. and MOSS, B. HATTON., HEYES, T., WILSON, D. and MOSS, B. Response of freshwater microcosm communities to nutrients, fish, and elevated temperature during winter and summer. Limnology and Oceanography, 2003, 48(2), 707-722. http://dx.doi.org/10.4319/ lo.2003.48.2.0707.

MIDDLETON, B.A. The flood pulse conception wetland restoration. New York: John Wiley \& Sons, 2002.

MORAIS, R.P., OLIVEIRA, L.G., LATRUBESSE, E.M. and PINHEIRO, R.C.D. Morfometria de sistemas lacustres da planície aluvial do médio Rio Araguaia. Acta scientiariun Biological Science, 2005, 27(3), 203-213.

NABOUT, J.C., CARNEIRO, F.M., BORGES, P.P., MACHADO, K.B. and HUSZAR, V.L.M. Brazilian scientific production on phytoplankton studies: national determinants and international comparisons. Brazilian Journal of Biology, 2015, 75(1), 216-223. http://dx.doi.org/10.1590/15196984.11713. PMid:25945640.

NABOUT, J.C., CARVALHO, P., PRADO, M.V., BORGES, P.P., MACHADO, K.B., HADAD, R.B., MICHELLAN, T.S., CUNHA, H.F. and SOARES, T.N. Trends and Biases in global climate change literature. Natureza \& Conservação, 2012, 10(1), 45-51. http://dx.doi.org/10.4322/natcon.2012.008.

NABOUT, J.C., NOGUEIRA, I.S. and OLIVEIRA, L.G. Phytoplankton community of floodplain lakes of the Araguaia River, Brazil, in the rainy and dry seasons. Journal of Plankton Research, 2006, 28(2), 181-193. http://dx.doi.org/10.1093/plankt/fbi111.

NABOUT, J.C., NOGUEIRA, I.S., OLIVEIRA, L.G. and MORAIS, R.R. Phytoplankton diversity (alpha, beta, and gamma) from the Araguaia River tropical floodplain lakes (central Brazil). Hydrobiologia, 2007, 557(1), 455-461. http://dx.doi.org/10.1007/s10750006-0393-8.

NABOUT, J.C., SIQUEIRA, T., BINI, L.M. and NOGUEIRA, I.S. No evidence for environmental and spatial processes in structuring phytoplankton communities. Acta Oecologica, 2009, 35(5), 720726. http://dx.doi.org/10.1016/j.actao.2009.07.002.

OKSANEN, F.J., BLANCHET, G., KINDT, R., LEGENDRE, P., MINCHIN, P.R., O'HARA, R.B., SIMPSON, G.L., SOLYMOS, P., STEVENS, M.H.H. and WAGNER, H. Vegan: Community Ecology Package. $R$ package version 2.2-1. 2015 [viewed 07 Nov 2015]. Available from: http:// CRAN.R-project.org/package=vegan

PITHART, D., PICHLOVÁ, R., BÍLÝ, M., HRBÁČEK, J., NOVOTNÁ, K. and PECHAR, L. Spatial and temporal diversity of small shallow waters in river Luznice floodplain. Hydrobiologia, 2007, 584(1), 265-275. http://dx.doi.org/10.1007/s10750-0070607-8.

SANDERSON, E.W., JAITEH, M., LEVY, M.A., REDFORD, K.H., WANNEBO, A.V. and WOOLMER, G. The Human Footprint and the Last of the Wild. Bioscience, 2002, 52(10), 891-904. http:// dx.doi.org/10.1641/0006-3568(2002)052[0891:TH FATL]2.0.CO;2.

SANO, E.E., ROSA, R., BRITO, J.L. and FERREIRA, L.G. Land cover mapping of the tropical savanna region in Brazil. Environmental Monitoring and Assessment, 2010, 166(1-4), 113-124. http://dx.doi. org/10.1007/s10661-009-0988-4. PMid:19504057.

SAWAKUCHI, H.O., BALLESTER, M.V.R. and FERREIRA, M.E. The Role of Physical and Political Factors on the Conservation of Native Vegetation in the Brazilian Forest-Savanna Ecotone. Open Journal of Forestry, 2013, 3(01), 49-56. http://dx.doi. org/10.4236/ojf.2013.31008.

SCHLEUPPER, C. and SCHNEIDER, U.A. Allocation of European wetland restoration options for systematic conservation planning. Land Use Policy, 2013, 30(1), 604-614. http://dx.doi.org/10.1016/j. landusepol.2012.05.008.

SOCIOECONOMIC DATA AND APPLICATIONS CENTER - SEDAC. [online]. United States: SEDAC Global Human Footprint, 2012 [viewed 20 Sep. 2012]. Available from: http://sedac.ciesin. org/data/set/wildareas-v2-human-footprint-ighp/ data-download/

STEVEN, D.D. and GRAMLING, J.M. Diverse characteristics of wetlands restored under the 
wetlands. Reserve Program in Southeastern United States. Wetlands, 2012, 32(4), 593-604. http://dx.doi. org/10.1007/s13157-012-0303-y.

TEFFERA, F.E., LEMMENS, P., DERIEMAECKER, A., BRENDONCK, L., DONDEYNE, S., DECKERS, J., BAUER, H., GAMO, F.W. and MEESTER, L.D. A call to action: strong long-term limnological changes in two largest Ethiopian Rift Valley lakes, Abaya and Chamo. Inland Waters, 2017, 7(2), 129-137. http://dx.doi.org/10.1080/2044204 1.2017.1301309.

THOMAZ, S.M., BINI, L.M. and BOZELLI, R.L. Floods increase similarity among aquatic habitats in river-floodplain systems. Hydrobiologia, 2007, 579(1), 1-13. http://dx.doi.org/10.1007/s10750006-0285-y.

TONOLLA, D., ACUNÁ, V., UEHLINGER, U., FRANK, T. and TOCKNER, K. Thermal heterogeneity in river floodplain. Ecossystems, 2010, 13(5), 727-740. http://dx.doi.org/10.1007/s10021010-9350-5.

TONOLLA, D., WOLTER, C., RUHTZ, T. and TOCKNER, K. Linking fish assemblages and spationtemporal thermal heterogeneity in a river floodplain landscape using high-resolution airborne thermal infrared remote sensing and insitu measurements. Remote Sensing of Environment, 2012, 125, 134-146. http://dx.doi.org/10.1016/j. rse.2012.07.014.

UNITED STATES GEOLOGICAL SURVEY - USGS. National Aeronautics and Space Administration - NASA. [online]. United States: USGS Landsat Missions, 2012 [viewed 15 May. 2012]. Available from: http://landsat.usgs.gov/

VALENTE, C.R., LATRUBESSE, E.M. and FERREIRA, L.G. Relationships among vegetation, geomorphology and hydrology in the Bananal Island tropical wetlands, Araguaia River basin, Central Brazil. Journal of South American Earth Sciences, 2013, 46, 150-160. http://dx.doi.org/10.1016/j. jsames.2012.12.003.

VAN DEN BRINK, F.W.B., VAN DEN VELDE, G. and WIJNHOVEN, S. Diversity, occurrence and feed in traits of caddisfly larvae as indicator for ecological integrity of river-floodplain habitats along a connectivity gradient. Ecological Indicators, 2013, 25, 219-232. http://dx.doi.org/10.1016/j. ecolind.2012.09.010.

VÖRÖSMARTY, C.J., MCINTYRE, P.B., GESSNER, M.O., DUdGEON, D., PRUSEVICH, A., GREEN, P., GLIDDEN, S., BUNN, S.E., SULLIVAN, C.A., LIERMANN, C.R. and DAVIES, P.M. Global threats to human water security and river biodiversity. Nature, 2010, 467(7315), 555-561. http://dx.doi.org/10.1038/ nature09440. PMid:20882010.

YE, X., ZHANG, Q., LIU, J., LI, X. and XU, C.Y. Distinguishing the relative impacts of climate change and human activities on variation of stream flow in the Poyang Lake catchment, China. Journal of Hydrology (Amsterdam), 2013, 494, 83-95. http:// dx.doi.org/10.1016/j.jhydrol.2013.04.036.

YUE, T.X., ZE-MEN, F., CHEN, C.F., SUN, X.F. and LI, B.L. Surface modelling of global terrestrial ecosystems under three climate change scenarios. Ecological Modelling, 2011, 222(14), 2342-236. http://dx.doi.org/10.1016/j.ecolmodel.2010.11.026.

Received: 11 November 2016 Accepted: 31 January 2019 